\title{
Recurrent tuberculosis among HIV-coinfected patients: a case series from KwaZulu-Natal
}

This article was published in the following Dove Press journal: Infection and Drug Resistance

\author{
Kogieleum Naidoo, ${ }^{1,2}$ \\ Navisha Dookie, ${ }^{1,3}$ Kasavan \\ Naidoo, ${ }^{2}$ Nonhlanhla \\ Yende-Zuma,' Benjamin \\ Chimukangara, ${ }^{1,3,4}$ Ambika \\ Bhushan,' Dhineshree \\ Govender,' Santhanalakshmi \\ Gengiah,' Nesri \\ Padayatchi ${ }^{1,2}$ \\ 'Centre for the AIDS Programme of \\ Research in South Africa (CAPRISA), \\ University of KwaZulu-Natal, \\ Durban, South Africa; ${ }^{2}$ South African \\ Medical Research Council (SAMRC) \\ - CAPRISA HIV-TB Pathogenesis and \\ Treatment Research Unit, Durban, \\ South Africa; ${ }^{3} \mathrm{~K}$ waZulu Natal \\ Research Innovation and Sequencing \\ Platform (KRISP), University of \\ KwaZulu-Natal, Durban, South Africa; \\ ${ }^{4}$ Department of Virology, National \\ Health Laboratory Service, University \\ of KwaZulu-Natal, Durban, \\ South Africa
}

Correspondence: Kogieleum Naidoo Doris Duke Medical Research Institute, University of KwaZulu-Natal, Private Bag $X 7$, Congella, Durban 4013, South Africa Tel +27 3I 2604687

Fax +27 3I 2604566

Email kogie.naidoo@caprisa.org
Background: Recurrent tuberculosis (TB) following TB treatment completion in HIV-infected individuals remains a major public health burden. We assessed the role of various risk factors in mediating the development of recurrent $\mathrm{TB}$ and subsequent resistance to antiretroviral therapy and anti-TB drugs.

Patients and methods: We analyzed secondary demographic, clinical, and laboratory data from medical records of five HIV-infected TB patients enrolled between 2009 and 2014 in a prospective observational study investigating TB recurrence. Paired clinical isolates of $\mathrm{Myco-}$ bacterium tuberculosis were typed by IS6110 restriction fragment length polymorphism analysis to determine the mechanism of TB recurrence. Plasma samples were genotyped to determine acquisition of HIV drug resistance mutations on antiretroviral treatment (ART).

Results: All five patients were HIV-coinfected, with a previous history of TB infection and prior exposure to anti-TB treatment, and residual lung damage, and demonstrated poor treatment adherence - significant risk factors linked to the development of recurrent TB disease. Furthermore, three of the five patients had multiple episodes of drug-susceptible TB infection with subsequent drug-resistant TB infection. Genotyping of the initial and recurrent M. tuberculosis isolates demonstrated three cases of recurrent TB because of relapse and two because of reinfection. All five patients had no mutations at ART initiation; however, by the end of the study follow-up, all patients developed dual class resistance.

Conclusion: This series demonstrates the complexity of recurrent TB in HIV coinfection. We highlight the challenges of managing coinfected patients and the increased propensity for the development of drug resistance. We report on the role of various risk factors mediating the development of resistance and subsequent clinical impact. This report underscores the need for structural clinical and adherence interventions for the management of complex treatment and dosing.

Keywords: adherence, TB-HIV coinfection, social risk factors, IS6110 RFLP, drug resistance

\section{Introduction}

Globally, tuberculosis (TB) presents as the most common opportunistic infection in people with HIV. ${ }^{1}$ In the latest global TB report, the World Health Organization estimated that $10 \%$ of the 10.4 million incident cases of TB in 2016 were coinfected with HIV. Sub-Saharan Africa bears the highest rates of HIV-associated TB, with coinfection rates of up to $50 \%$ in some areas. ${ }^{1}$ In HIV-uninfected individuals with latent $\mathrm{TB}$ infection, the lifetime risk of $\mathrm{TB}$ reactivation disease is $10 \%$. This risk is increased to $10 \%$ per annum in HIV-infected patients. ${ }^{2}$ In addition to the increased risk of TB reactivation, HIV coinfection has also been reported as a significant risk 
factor for recurrent TB disease. Weakened immune responses, a hallmark characteristic of HIV infection, facilitates the progression to active $\mathrm{TB}$ disease and is a significant risk factor for recurrent TB disease. ${ }^{3}$ HIV-TB coinfection is further complicated by the development of drug resistance in Mycobacterium tuberculosis. ${ }^{4-6}$

Recurrent TB disease, following cure or successful treatment completion, occurs as a result of either relapse (recurrence of the previous infection) or reinfection (infection with a new strain type), each associated with its own risk factors. Risk factors associated with individual vulnerability including immune compromise due to comorbidities such as HIV coinfection and diabetes mellitus, residual lung damage due to previous TB infection, age, malnutrition, and social risk factors such as alcohol abuse and cigarette smoking have been attributed to both relapse and reinfection. Risk factors that impact on treatment response such as inadequate treatment regimen, poor treatment adherence, and unrecognized drug resistance or host-specific factors that affect drug metabolism have been attributed to relapse of TB disease. Increased risk due to poor epidemic or infection control resulting in repeat exposure has been attributed to reinfection. Distinguishing between relapse and reinfection requires comparing the homology of $M$. tuberculosis strains isolated during the first and recurrent TB episodes using molecular-based DNA fingerprinting techniques. ${ }^{7,8}$

Complex multi-drug regimens and optimal medication adherence are required for effective treatment of TB/HIV coinfection. ${ }^{9-11}$ This results in challenges of adherence to complex dosing strategies, long duration of therapy, serious and often life-threatening drug side effects, and drug-drug interactions. ${ }^{11}$ Adherence, a major factor undermining treatment outcomes, relies on patients' attitude, knowledge, and beliefs, which are in turn influenced by poverty, gender, stigma, and other social and cultural factors. ${ }^{9-14}$ Patients failing TB treatment are likely to remain infectious thereby increasing the likelihood of ongoing transmission of infection. ${ }^{9,15,16}$ We report and analyze five patients with HIV-TB coinfection, receiving concomitant treatment for both diseases and who subsequently developed recurrent drugresistant TB (DR-TB). This report highlights the various risk factors that contributed to the development of recurrent TB.

\section{Patients and methods}

We conducted a retrospective chart review on a subset of patients enrolled in the CAPRISA TRuTH study investigating the incidence of TB recurrence in adult TB/HIV-coinfected patients, who previously completed treatment for drug-sensitive pulmonary TB in the CAPRISA SAPiT trial. ${ }^{17}$ The study was conducted between June 2005 and August 2013. Patients were followed up quarterly for 5 years. Among 82 patients who developed recurrent $\mathrm{TB}$, five patients were diagnosed with recurrent DR-TB. Case notes were used to report the contributing risk factors to the development of recurrent TB.

Patients diagnosed were treated with standard TB treatment, and treatment outcomes were recorded as per the South African National TB control program guidelines. ${ }^{18}$ Patients were initiated on a once-daily first-line antiretroviral treatment (ART) regimen and managed as per national guidelines. ${ }^{19}$ Participants received TB treatment adherence - counseling occurred prior to TB treatment initiation, and adherence was enhanced and verified through TB directly observed therapy short-course (DOTS) program. ART adherence support occurred through group counseling, two sessions prior to initiation, one on the day of treatment, and continued six-monthly thereafter. Adherence was assessed by clinic-based pill count at all scheduled visits, and six-monthly virologic outcomes. Adherence was described according to previously published categories by medication possession ratios and patient self-reporting.

To determine the mechanism mediating TB recurrence, initial and recurrent isolates were genotyped using the IS6110 restriction fragment length polymorphism method. ${ }^{22,23}$ To assess the impact of HIV on TB recurrence, HIV virologic markers were assessed and stored plasma samples were analyzed for drug resistance conferring mutations prior to ART initiation, at the entry of the TRuTH study, and at the end of the study. HIV drug resistance sequencing incorporated the viral protease (codons 1-99) and reverse transcriptase (codons 1-230) genes. Drug resistance mutations were interpreted using the Stanford University HIV drug resistance database ${ }^{16,18}$ and the International AIDS Society mutation list. ${ }^{19}$

Ethical approval for the TRuTH study was obtained from the University of KwaZulu-Natal Biomedical Ethics Research Committee, reference number BF051/09; Clinical trials number NCT01539005. Written informed consent was obtained from all participants to publish case details and images with no personal identifiers.

\section{Results}

In-depth clinical profiles for each patient are described in Table 1 . The mean age was 34.8 (range, 30-38) years during the first TB episode. Among the five participants, two were female and three were male. One patient displayed a body mass index (BMI) of 17.0, falling within the underweight 
Table I Epidemiologic and clinical characteristics of five patients with recurrent (M) XDR-TB following drug-susceptible TB

\begin{tabular}{|c|c|c|c|c|c|}
\hline $\begin{array}{l}\text { Clinical and epidemiologic } \\
\text { biomarker }\end{array}$ & Patient I & Patient 2 & Patient 3 & Patient 4 & Patient 5 \\
\hline Age & 38 & 32 & 38 & 36 & 30 \\
\hline Gender & $M$ & $M$ & $\mathrm{~F}$ & $\mathrm{~F}$ & $\mathrm{~F}$ \\
\hline \multicolumn{6}{|l|}{ BMI } \\
\hline $\mathrm{BMI}$ at TB-I diagnosis & 19.4 & 18.7 & 17.6 & 21.4 & 26 \\
\hline BMI at TB-I end & 18.4 & 20.5 & 18.7 & 23.2 & 26.5 \\
\hline BMI at TB-2 diagnosis & 21.3 & 20.4 & 17.0 & 19.4 & 25.8 \\
\hline \multicolumn{6}{|l|}{ Initial episode of TB } \\
\hline \multirow[t]{2}{*}{ Date and method of diagnosis } & Jul 2007 & Jul 2007 & Jan 2007 & Nov 2007 & Aug 2005 \\
\hline & X-ray + sputum & X-ray + sputum & X-ray + sputum & X-ray + sputum & $X$-ray + sputum \\
\hline Genetic and susceptibility & Beijing & FI5/LAM4/KZN & $\mathrm{F} 28$ & $\mathrm{~F} 28$ & Unique \\
\hline profile & DS-TB & $\begin{array}{l}\text { DS-TB } \\
\text { Lymph aspirate } \\
\text { resistant to INH } \\
\text { and RIF }\end{array}$ & DS-TB & DS-TB & DS-TB \\
\hline Chest radiograph & $\begin{array}{l}\text { Infiltrates on } \\
\text { RL; cavities and } \\
\text { infiltrates on LL }\end{array}$ & $\begin{array}{l}\text { Infiltrates on } \mathrm{RL} \\
\text { and } \mathrm{LL}\end{array}$ & $\begin{array}{l}\text { Cavities, } \\
\text { infiltrates, } \\
\text { pleural disease, } \\
\text { and shrinkage } \\
\text { and destruction } \\
\text { in RL, minimal } \\
\text { fibrosis on LL }\end{array}$ & $\begin{array}{l}\text { Cavities and } \\
\text { infiltrates in RL } \\
\text { and } \mathrm{LL}\end{array}$ & $\begin{array}{l}\text { Cavities and } \\
\text { infiltrates in } R L \\
\text { and } L L\end{array}$ \\
\hline \multirow{3}{*}{$\begin{array}{l}\text { Completion date, duration on } \\
\text { treatment and outcome }\end{array}$} & I April 2008 & 20 March 2008 & 20 August 2007 & Jun 302008 & 02 January 06 \\
\hline & 8 months & 8 months & 10 months & 7 months & 6 months \\
\hline & Cure & Cure & Cure & Cure & Cure \\
\hline $\begin{array}{l}\text { Chest radiograph at the end } \\
\text { of treatment } \\
\text { Recurrent MDR/XDR episode } \\
\text { of TB }\end{array}$ & $\begin{array}{l}\text { Fibrosis in upper } \\
\text { RL }\end{array}$ & Fibrosis in LL & Extensive fibrosis & Not available & Not available \\
\hline Mechanism of recurrence, & Reinfection & Relapse & Reinfection & Relapse & Relapse \\
\hline genetic profile of TB isolates & Beijing to $K Z N$ & $\mathrm{KZN}$ strain & F28 - unique & F28 strain & Unique strain \\
\hline and time to recurrence & $\begin{array}{l}\text { strain } \\
24 \text { months }\end{array}$ & 28 months & 19 months & 28 months & 15 months \\
\hline \multirow{2}{*}{ Date and method of diagnosis } & June 10 & Feb 20II & Apr 2010 & Nov 2010 & May 07 \\
\hline & $\begin{array}{l}\text { X-ray }+ \text { sputum } \\
\text { culture }\end{array}$ & X-ray + sputum & $\begin{array}{l}\text { X-ray }+ \text { sputum } \\
\text { culture }\end{array}$ & X-ray + sputum & X-ray + sputum \\
\hline \multirow[t]{2}{*}{ Susceptibility profile } & XDR-TB & MDR-TB & MDR-TB & MDR-TB & XDR-TB \\
\hline & $\begin{array}{l}\text { Resistant to } \\
\text { INH, RIF, EMB, } \\
\text { kanamycin, } \\
\text { capreomycin, OFX, } \\
\text { laliamide, SM, ETH, } \\
\text { and PZA }\end{array}$ & $\begin{array}{l}\text { Resistant to INH, } \\
\text { RIF, EMB, ETH, } \\
\text { PZA, and SM }\end{array}$ & $\begin{array}{l}\text { Resistant to NH, } \\
\text { RIF, ETH, SM, } \\
\text { and PZA }\end{array}$ & $\begin{array}{l}\text { Resistant to INH, } \\
\text { EMB, RIF, SM, ETH, } \\
\text { and PZA }\end{array}$ & $\begin{array}{l}\text { INH, RIF, EMB, } \\
\text { MXF, KANA, } \\
\text { and ETH }\end{array}$ \\
\hline Radiologic findings & $\begin{array}{l}\text { Infiltrates on RL } \\
\text { and infiltrates and } \\
\text { new lesions on LL }\end{array}$ & Cavities in LL & $\begin{array}{l}\text { Bullae and plural } \\
\text { effusion in RL }\end{array}$ & $\begin{array}{l}\text { Cavities and } \\
\text { infiltrates on } \mathrm{RL} \\
\text { and fibrosis on } \mathrm{LL}\end{array}$ & Cavitation in LL \\
\hline Treatment outcome & $\begin{array}{l}\text { Transferred out for } \\
\text { DR-TB care }\end{array}$ & $\begin{array}{l}\text { Transferred out for } \\
\text { DR-TB care }\end{array}$ & Died & $\begin{array}{l}\text { Withdrew from } \\
\text { study }\end{array}$ & $\begin{array}{l}\text { Transferred out } \\
\text { for DR-TB care }\end{array}$ \\
\hline \multicolumn{6}{|l|}{ HIV history } \\
\hline Date of diagnosis & Jul 2007 & Jul 2007 & Jan 2007 & Dec 2007 & 2005 \\
\hline Treatment regimen & $\begin{array}{l}\text { AZT/3TC/EFV, } \\
\text { switched AZT to } \\
\text { TDF in May } 2009\end{array}$ & $\begin{array}{l}\text { ddI/3TC/EFV } \\
\text { (discontinued } \\
\text { between March and } \\
\text { April 2009) }\end{array}$ & $\mathrm{ddl} / 3 \mathrm{TC} / \mathrm{EFV}$ & $\begin{array}{l}\mathrm{ddl} / 3 \mathrm{TC} / \mathrm{EFV} \\
\text { switched to } \mathrm{ABC} / \\
\text { TDF/LPV/r in } \\
\text { October } 2008 \text {, and } \\
\text { back to regimen I } \\
\text { in June } 201 \mathrm{l}\end{array}$ & $\begin{array}{l}\mathrm{ddl} / 3 \mathrm{TC} / \mathrm{EFV} \text {, } \\
\text { switched to } \\
\text { TDF in July } \\
201 \mathrm{I}\end{array}$ \\
\hline
\end{tabular}


Table I (Continued)

\begin{tabular}{|c|c|c|c|c|c|}
\hline $\begin{array}{l}\text { Clinical and epidemiologic } \\
\text { biomarker }\end{array}$ & Patient I & Patient 2 & Patient 3 & Patient 4 & Patient case 5 \\
\hline Regimen response & $\begin{array}{l}\text { Virologic } \\
\text { suppression; } \\
\text { sustained high } \\
\text { CD4+ cell count }\end{array}$ & $\begin{array}{l}\text { Raised CD4 count } \\
\text { and virologic } \\
\text { suppression by } \\
\text { Month } 12\end{array}$ & $\begin{array}{l}\text { Good virologic } \\
\text { suppression, } \\
\text { CD4 cell count } \\
\text { remained low }\end{array}$ & $\begin{array}{l}\text { Failed both } \\
\text { regimens, placed } \\
\text { back onto Regimen } \\
\text { I }\end{array}$ & $\begin{array}{l}\text { Good virologic } \\
\text { suppression, } \\
\text { CD4 count } \\
\text { remained low }\end{array}$ \\
\hline CD4/VL at initial TB diagnosis & $\begin{array}{l}C D 4=200 \\
V L=260,000\end{array}$ & $\begin{array}{l}C D 4=54 \\
V L=126,000\end{array}$ & $\begin{array}{l}C D 4=|5| \\
V L=4 \mid, 663\end{array}$ & $\begin{array}{l}\text { CD4 }=245 \\
\mathrm{VL}=\text { Unavailable }\end{array}$ & $\begin{array}{l}C D 4=205 \\
V L=83,900\end{array}$ \\
\hline $\begin{array}{l}C D 4 / V L \text { at the end of first TB } \\
\text { episode }\end{array}$ & $\begin{array}{l}C D 4=434 \\
V L=400\end{array}$ & $\begin{array}{l}C D 4=377 \\
V L \leq 400\end{array}$ & $\begin{array}{l}\mathrm{CD} 4=33 \mathrm{I} \\
\mathrm{VL} \leq 400\end{array}$ & $\begin{array}{l}C D 4=212 \\
V L=27,400\end{array}$ & $\begin{array}{l}C D 4=352 \\
V L \leq 400\end{array}$ \\
\hline $\begin{array}{l}\mathrm{CD} 4 / \mathrm{VL} \text { at recurrent } \mathrm{TB} \\
\text { diagnosis }\end{array}$ & $\begin{array}{l}\mathrm{CD} 4=3,652 \\
\mathrm{VL}=\text { unavailable }\end{array}$ & $\begin{array}{l}C D 4=565 \\
\vee \leq 400\end{array}$ & $\begin{array}{l}\mathrm{CD} 4=245 \\
\mathrm{VL} \leq 40\end{array}$ & $\begin{array}{l}C D 4=143 \\
V L=20,302\end{array}$ & $\begin{array}{l}C D 4=204 \\
V L=69,400\end{array}$ \\
\hline Other notes & & & & & \\
\hline TB risk profile & Hospitalization & Hospitalization & Hospitalization & $\begin{array}{l}\text { Household TB } \\
\text { contacts }\end{array}$ & No risks \\
\hline Adherence profile & $\begin{array}{l}\text { Poor; adherence } \\
\text { support program }\end{array}$ & $\begin{array}{l}\text { Fair; missed } \\
\text { clinic visits due } \\
\text { to alcohol use, } \\
\text { occasional missing } \\
\text { of doses }\end{array}$ & Good & $\begin{array}{l}\text { Poor; } \\
\text { hospitalization } \\
\text { for supervised TB } \\
\text { treatment }\end{array}$ & Good \\
\hline Other medical conditions & $\begin{array}{l}\text { Anemia, PN, SN, } \\
\text { HepB }\end{array}$ & $\begin{array}{l}\text { IRIS on TB } \\
\text { treatment, PN }\end{array}$ & $\begin{array}{l}\mathrm{PN} \text {, pneumonia } \\
\text { in August } 2010\end{array}$ & Hypertension, PN & None \\
\hline Substance use history & $\begin{array}{l}\text { Alcohol abuse, } \\
\text { smoking }\end{array}$ & $\begin{array}{l}\text { Alcohol abuse, } \\
\text { smoking }\end{array}$ & None & None & None \\
\hline
\end{tabular}

Notes: Initial episode of TB = TB-I; Recurrent episode of TB = TB-2 radiological findings from chest $x$-rays conducted after diagnosis and treatment end (closest date available given).

Abbreviations: 3TC, lamivudine; $A B C$, abacavir; ALV, alluvia; AZT, azidothymidine; BMI, body mass index; CD4, CD4+ T-cell count (cells/ $\mu L^{3}$ ); DDI, didanosine; EFV, efavirenz; EMB, ethambutol; ETH, ethionamide; Hep B, hepatitis B; INH, isoniazid; LL, left lung; MDR, multi-drug-resistant; OFX, ofloxacin; PN, peripheral neuropathy; PTB, pulmonary TB; PZA, pyrazinamide; R4, Rifafour; RIF, rifampicin; RL, right lung; SM, streptomycin; SN, sensory neuropathy; TB, tuberculosis; TDF, tenofovir; VL, viral load $\left(\right.$ copies $\left./ \mu L^{3}\right) ; X D R$, extensively drug-resistant.

range during the recurrent $\mathrm{TB}$ episode. The remaining patients recorded BMI values in the normal range.

\section{TB history and associated risk factors for recurrent TB}

All five patients had a previous history of TB disease for which they received between 6 and 10 months of DS anti-TB treatment, before enrolling into the TRuTH study. Patients 1 and 5 subsequently developed XDR-TB, and the remaining patients developed MDR-TB. Patients 1, 2, and 3 presented with DR-TB in the TRuTH study 24, 28, and 19 months, respectively, after successful treatment completion for two prior episodes of DS-TB. Patients 4 and 5 presented with DR-TB during the TRuTH study 28 and 15 months, respectively, after successful treatment completion for one episode of DS-TB. Assessment of radiographic chest X-rays during initial TB infection, point of cure for initial TB episode, and TB relapse (Figures S1-S4 and Table 1) indicated that recurrent TB infection was characterized by the presence of vast damage to the lungs and residual damage from prior $\mathrm{TB}$ infection. Month 2 sputum culture results were only available for patients 1 and 2, both of which remained positive. The remaining patients had only sputum smear results available, all of which were negative. Among the paired M. tuberculosis isolates representing the initial and recurrent TB episodes, there were two cases of TB reinfection (patients 1 and 3 ) and three cases of TB relapse (patients 2, 4, and 5). Detailed data on genetic profiles, drug susceptibility profiles, and timelines for recurrent disease episodes are reported in Table 1.

\section{HIV coinfection and its impact on recurrent TB disease}

All five patients were diagnosed with HIV at screening of the SAPiT trial and initiated on standard treatment at various points during concomitant anti-TB therapy. The mean $\mathrm{CD}^{+} \mathrm{T}$ cell count was $171 \mathrm{cells} / \mathrm{mm}^{3}$ at diagnosis of the initial TB episode, 341,2 cells $/ \mathrm{mm}^{3}$ at cure of the first TB episode and 289 cells $/ \mathrm{mm}^{3}$ at diagnosis of recurrent TB. CD4 and viral load data for each patient are detailed in Table 1. Retrospective analysis of HIV drug resistance mutations demonstrated that the patients had no pre-ART drug resistance mutations. However, over the course of treatment and 
subsequent regimen changes, by the end of the study all patients developed dual class resistance with non-nucleoside reverse transcriptase inhibitor (NNRTI) mutations featuring prominently. Protease inhibitor resistance mutations were not detected in any of the patients described. Detailed data on all resistance-associated mutations over the course of treatment are shown in Table 2.

\section{Adherence and social risk factors}

There were various social risk factors and treatment adherence issues that played a role in the complex clinical course of these patients. Patient 1 had a history of alcohol abuse resulting in poor adherence, missed clinic visits, and discontinuation of ART for a period of 6 months. The patient's hospital admission also coincided with diagnosis of his recurrent TB episode. Patient 2 also had a reported history of alcohol abuse resulting in poor adherence and incarceration that coincided with his MDR-TB diagnosis. Patient 3 reported that her partner was HIV positive who was not on ART and declined condom use with her. In addition, this patient reported a low level of educational attainment. Patient 4 displayed poor adherence despite receiving intensive counseling under study conditions. She also reported close contacts with TB patients, no condom use, and low level of educational attainment. Patient 5 reported no significant adherence or social risk factors.

\section{Discussion}

This series highlights the impact of various risk factors in the development of recurrent TB infection in five HIV-coinfected patients. We further highlight the considerable complexity in the management of coinfected patients because of the use of multiple drugs with complex dosing schedules, and prolonged treatment course that is often complicated by severe overlapping drug toxicities. Published data from various settings consistently demonstrate the impact of these factors on patient adherence and retention in care..$^{20,21,24,25}$

Notwithstanding the small sample size in this case series, the following important findings should be noted. All five patients were HIV coinfected with a previous history of TB infection and prior exposure to anti-TB treatment, residual lung damage, and demonstration of poor treatment adherence; significant risk factors linked to the development of recurrent TB disease. Furthermore, three of the five patients had multiple episodes of DS-TB infection with subsequent DR-TB infection. Strain typing revealed that recurrence occurred by relapse in three cases and by reinfection in two cases. While published reports attribute reinfection as the main mechanism of recurrence in the context of HIV coinfection, we demonstrated three cases of relapse in our study among HIV/TB-coinfected patients. ${ }^{26-29}$ Furthermore, our data support findings of a recent South African study showing ongoing transmission of DR-TB, and the low rates of TB culture conversion including frequent reversion. ${ }^{6}$

We retrospectively analyzed the development of ART resistance mutations in our recurrent TB patients. Despite having no mutations at ART initiation, by the end of the study all five patients developed dual class resistance with NNRTI mutations featuring prominently. The considerable pill burden imposed by the addition of DR-TB treatment to chronic ART is likely to have negatively impacted ART adherence fueling development of ART resistance. These findings are consistent with the published surveillance studies conducted in this setting, reporting the mutations detected in this study as prevalent mutations associated with acquired resistance in adults. ${ }^{15,30-34}$ Retrospective analysis of the resistance mutations reveals that patients were receiving inadequate ART for optimal viral suppression. Furthermore, guidelines advocate first-line ART regimen switch without the benefit of ART resistance testing. This coupled with the lack of objective markers of ART adherence comprises early detection and management of ART failure. Most importantly, these cases highlight the need for ongoing clinical monitoring for treatment failure and HIV resistance testing, especially in patients taking complex regimen for multiple concurrent conditions.

Suboptimal adherence to treatment was a key factor driving drug resistance in this subset of patients. Despite receiving enhanced counseling support under clinical trial conditions, patients remained nonadherent. In keeping with previous reports, known behavioral and biologic risk factors such as alcohol misuse, incarceration, hospital admission, poor pill-taking behavior, low level of education attainment, and missed clinic appointments featured among patients failing treatment and acquiring resistance in this study. Despite access to free care for both HIV and TB, underlying social issues severely impacted treatment outcomes underscoring the need for strong ongoing support directed at optimizing treatment adherence and treatment completion. ${ }^{9,14,16,35-39}$ DOTS programs played a pivotal role in increasing treatment completion rates globally. Adopting a similar strategy for the management of DR-TB and HIV coinfection could impact on reducing recurrent TB rates. ${ }^{40-42}$ As reinfection rates are higher in HIV endemic settings like South Africa, we also highlight the need for enhanced infection control measures 
Table 2 HIV drug resistance profiles at TRUTH study entry and exit visits

\begin{tabular}{|c|c|c|c|}
\hline & ART regimen & $\begin{array}{l}\text { Drug resistance mutations at } \\
\text { TRUTH entry }\end{array}$ & $\begin{array}{l}\text { Drug resistance mutations } \\
\text { at the end of TRUTH study }\end{array}$ \\
\hline \multirow[t]{2}{*}{ Patient I } & $\mathrm{AZT} / 3 \mathrm{TC} / \mathrm{EFV}$ switched to TDF/3TC/EFV & NRTI: D67N; K70R; MI84V; T2I5/a; K219E & NRTI: MI84V \\
\hline & & NNRTI: VI06M; YI88F; M230L & NNRTI: KI03N; GI90A; YI88L \\
\hline \multirow[t]{2}{*}{ Patient 2} & ddl/3TC/EFV & None & NRTI: MI84V \\
\hline & & & NNRTI: VI06M; YI88L \\
\hline \multirow{2}{*}{ Patient 3} & $\mathrm{ddl} / 3 \mathrm{TC} / \mathrm{EFV}$ & NRTI: T2I5S & NRTI: K70E; MI84V \\
\hline & & NNRTI: KI03N & NNRTI: KI03N \\
\hline \multirow[t]{2}{*}{ Patient 4} & ddI/3TC/EFV switched to ABC/TDF/ & None & NRTI: MI84V \\
\hline & LPV/r then switched back to ddl/3TC/EFV & & NNRTI: KIOIE; KI03N; GI90A \\
\hline \multirow[t]{2}{*}{ Patient 5} & ddl/3TC/EFV switched to TDF/3TC/EFV & None & NRTI: MI84I \\
\hline & & & NNRTI: VI06M; Y188C; H22IY \\
\hline
\end{tabular}

Notes: aRevertant mutation; ${ }^{\mathrm{b}}$ Transitional mutation. None of the patients had any resistance associated mutation prior to the initiation of treatment.

Abbreviations: 3TC, lamivudine; ABC, abacavir; ddl, didanosine; AZT, zidovudine; EFV, efavirenz; NNRTI, non-nucleoside reverse transcriptase inhibitor; NRTI, nucleoside reverse transcriptase inhibitor; LPV/r, lopinavir-boosted ritonavir (Aluvia; Abbott, South Africa).

and ongoing surveillance in congregate settings such as clinic waiting rooms, hospitals, and prisons..$^{43,44}$

We would like to acknowledge study limitations. Secondary study data and stored samples from the study biorepository were analyzed. We had to rely on self-reported information regarding prior ARV treatment and ART and TB adherence. The lack of availability of objective markers of adherence undermines our ability to understand the evolution of drug resistance to ART and TB drugs. Furthermore, the small sample size limits the generalizability of our findings to other patients and settings. We also did not establish if these patients had mixed strain infection and the extent to which this might have influenced our findings.

In conclusion, the cases described in this series highlight the public health crisis resulting from the intersecting epidemics of DR-TB and drug-resistant HIV. The study underscores the complexity of managing TB and HIV coinfection, and the impact of various risk factors in mediating resistance. Patients failing treatment present a public health risk of ongoing transmission of resistant strains. Distinguishing between relapse and reinfection plays an invaluable role in addressing the burden of recurrent TB disease. High rates of relapse underscore the need for renewed interventions to improve individual patient care while high rates of reinfection underscore the need for improved epidemic control measures. Urgent attention is also required to address challenges of adherence, such as social and health care worker support systems and step-down management facilities. Enhanced treatment options, such as intensified initial treatment, extension of treatment, and preventative therapy for patients presenting with multiple risk factors, will prevent recurrent TB infection. The heightened risk of recurrent TB in ART programs underscores the need for regular TB screening at
ART follow-up visits . There has been considerable disparity in the studies reporting on the role of relapse vs reinfection. Further large-scale studies are required to address the role of relapse and reinfection as well as the role of mixed infections in recurrent TB.

\section{Acknowledgments}

The authors would like to thank the CAPRISA clinic team and participants of the SAPiT and TRuTH studies at the eThekwini Clinic.

This study was supported by the US President's Emergency Plan for AIDS Relief (PEPFAR), the Global Fund to fight AIDS, Tuberculosis and Malaria and the National Institutes of Health Comprehensive International Program of Research on AIDS. KN and NP were supported by the Columbia University-South Africa Fogarty AIDS International Training and Research Program (AITRP, Grant D43 TW000231).

\section{Disclosure}

The authors report no conflicts of interest in this work.

\section{References}

1. World Health Organization. Global Tuberculosis Report; 2015. Available from: http://apps.who.int/iris/bitstream/10665/191102/1/9789241565059_ eng.pdf.

2. Kwan CK, Ernst JD. HIV and tuberculosis: a deadly human syndemic. Clin Microbiol Rev. 2011;24(2):351-376.

3. Sonnenberg P, Murray J, Glynn JR, Shearer S, Kambashi B, GodfreyFaussett P. HIV-1 and recurrence, relapse, and reinfection of tuberculosis after cure: a cohort study in South African mineworkers. Lancet. 2001;358(9294):1687-1693.

4. O'Donnell MR, Padayatchi N, Kvasnovsky C, Werner L, Master I, Horsburgh CR. Treatment outcomes for extensively drugresistant tuberculosis and HIV co-infection. Emerg Infect Dis. 2013;19(3):416-424. 
5. Shafer RW. HIV-1 Drug Resistance Testing-A Brief Review of the Main Clinical Issues. Business Briefing: Long-Term Healthcare; 2004:48998-49009.

6. Pietersen E, Ignatius E, Streicher EM, et al. Long-term outcomes of patients with extensively drug-resistant tuberculosis in South Africa: a cohort study. Lancet. 2014;383(9924):1230-1239.

7. Mcivor A, Koornhof H, Kana BD, Relapse KBD. Relapse, re-infection and mixed infections in tuberculosis disease. Pathog Dis. 2017;75(3).

8. Guerra-Assunção JA, Houben RM, Crampin AC, et al. Recurrence due to relapse or reinfection with Mycobacterium tuberculosis: a wholegenome sequencing approach in a large, population-based cohort with a high HIV infection prevalence and active follow-up. J Infect Dis. 2015;211(7):1154-1163

9. O'donnell MR, Wolf A, Werner L, Horsburgh CR, Padayatchi N. Adherence in the treatment of patients with extensively drug-resistant tuberculosis and HIV in South Africa. J Acquir Immune Defic Syndr. 2014;67(1):22-29.

10. Shean K, Streicher E, Pieterson E, et al. Drug-associated adverse events and their relationship with outcomes in patients receiving treatment for extensively drug-resistant tuberculosis in South Africa. PLoS One. 2013;8(5):e63057.

11. CDC [webpage on the Internet]. Managing drug interactions in the treatment of HIV-related tuberculosis. Available from: http://www.cdc. gov/tb/TB_HIV_Drugs/default.htm. Accessed July 6, 2017.

12. O'Connor JL, Gardner EM, Mannheimer SB, et al. Factors associated with adherence amongst 5295 people receiving antiretroviral therapy as part of an international trial. J Infect Dis. 2013;208(1):40-49.

13. Kulkarni P, Akarte S, Mankeshwar R, Bhawalkar J, Banerjee A, Kulkarni A. Non-adherence of new pulmonary tuberculosis patients to anti-tuberculosis treatment. Ann Med Health Sci Res. 2013;3(1):67-74.

14. Daftary A, Padayatchi N, O'Donnell M. Preferential adherence to antiretroviral therapy over tuberculosis treatment: a qualitative study of drug-resistant TB/HIV co-infected patients in South Africa. Glob Public Health. 2014;9(9):1107-1116.

15. Kiepiela P. HIV drug resistance patterns at the epicentre of the HIV-1 epidemic in Kwazulu-Natal, South Africa 2003-2013. JAIDS Clin Res. 2014;5(5).

16. Dheda K, Gumbo T, Gandhi NR, et al. Global control of tuberculosis: from extensively drug-resistant to untreatable tuberculosis. Lancet Respir Med. 2014;2(4):321-338.

17. Abdool Karim SS, Naidoo K, Grobler A, et al. Timing of initiation of antiretroviral drugs during tuberculosis therapy. $N$ Engl $J$ Med. 2010;362(8):697-706.

18. South African Department of Health. National tuberculosis management guidelines; 2014. Available from: http://www.sahivsoc.org/upload/documents/NTCP_Adult_TB\%20Guidelines\%2027.5.2014.pdf. Accessed July 14, 2016.

19. South African Department of Health [webpage on the Internet]. Guidelines for the use of antiretroviral agents in HIV-1 infected adults and adolescents. Available from: https://aidsinfo.nih.gov/guidelines/html/1/ adult-and-adolescent-treatment-guidelines/0. Accessed July 14, 2016

20. Weidle PJ, Wamai N, Solberg P, et al. Adherence to antiretroviral therapy in a home-based AIDS care programme in rural Uganda. The Lancet. 2006;368(9547):1587-1594.

21. Nachega JB, Hislop M, Dowdy DW, et al. Adherence to highly active antiretroviral therapy assessed by pharmacy claims predicts survival in HIV-infected South African adults. J Acquir Immune Defic Syndr. 2006;43(1):78-84.

22. van Soolingen D, Hermans PW, de Haas PE, Soll DR, van Embden JD. Occurrence and stability of insertion sequences in Mycobacterium tuberculosis complex strains: evaluation of an insertion sequence-dependent DNA polymorphism as a tool in the epidemiology of tuberculosis. J Clin Microbiol. 1991;29(11):2578-2586.
23. van Embden JD, Cave MD, Crawford JT, et al. Strain identification of Mycobacterium tuberculosis by DNA fingerprinting: recommendations for a standardized methodology. J Clin Microbiol. 1993;31(2):406-409.

24. Meintjes G. Management of drug-resistant TB in patients with HIV co-infection. J Int AIDS Soc. 2014;17(4 Suppl 3):19508.

25. Tiberi S, Carvalho AC, Sulis G, et al. The cursed duet today: tuberculosis and HIV-coinfection. Presse Med. 2017;46(2 Pt 2):e23-e39.

26. Uys PW, van Helden PD, Hargrove JW. Tuberculosis reinfection rate as a proportion of total infection rate correlates with the logarithm of the incidence rate: a mathematical model. JR Soc Interface. 2009;6(30):11-15.

27. Verver $\mathrm{S}$, Warren RM, Beyers N, et al. Rate of reinfection tuberculosis after successful treatment is higher than rate of new tuberculosis. $A m$ $J$ Respir Crit Care Med. 2005;171(12):1430-1435.

28. Glynn JR, Murray J, Bester A, Nelson G, Shearer S, Sonnenberg P. High rates of recurrence in HIV-infected and HIV-uninfected patients with tuberculosis. J Infect Dis. 2010;201(5):704-711.

29. Narayanan S, Swaminathan S, Supply P, et al. Impact of HIV infection on the recurrence of tuberculosis in South India. J Infect Dis. 2010;201(5):691-703.

30. Marconi VC, Sunpath H, Lu Z, et al. Prevalence of HIV-1 drug resistance after failure of a first highly active antiretroviral therapy regimen in KwaZulu Natal, South Africa. Clin Infect Dis. 2008;46(10):1589-1597.

31. Murphy RA, Sunpath H, Lu Z, et al. Outcomes after virologic failure of first-line ART in South Africa. AIDS. 2010;24(7):1007-1012.

32. Singh A, Sunpath H, Green TN, et al. Drug resistance and viral tropism in HIV-1 subtype C-infected patients in KwaZulu-Natal, South Africa: implications for future treatment options. J Acquir Immune Defic Syndr. 2011;58(3):233.

33. Manasa J, Lessells RJ, Skingsley A, et al. High-levels of acquired drug resistance in adult patients failing first-line antiretroviral therapy in a rural HIV treatment programme in KwaZulu-Natal, South Africa. PLoS One. 2013;8(8):e72152.

34. Coffin JM. HIV population dynamics in vivo: implications for genetic variation, pathogenesis, and therapy. Science. 1995;267(5197): 483-489.

35. Cohen T, van Helden PD, Wilson D, et al. Mixed-strain mycobacterium tuberculosis infections and the implications for tuberculosis treatment and control. Clin Microbiol Rev. 2012;25(4):708-719.

36. Skrahina A, Hurevich $\mathrm{H}$, Zalutskaya A, et al. Multidrug-resistant tuberculosis in Belarus: the size of the problem and associated risk factors. Bull World Health Organ. 2013;91(1):36-45.

37. Andrews JR, Shah NS, Weissman D, Moll AP, Friedland G, Gandhi NR. Predictors of multidrug- and extensively drug-resistant tuberculosis in a high HIV prevalence community. PLoS One. 2010;5(12): e15735.

38. Balaji V, Daley P, Anand AA, et al. Risk factors for MDR and XDR-TB in a tertiary referral hospital in India. PLoS One. 2010;5(3):e9527.

39. Zhao P, Li XJ, Zhang SF, Wang XS, Liu CY. Social behaviour risk factors for drug resistant tuberculosis in mainland China: a meta-analysis. J Int Med Res. 2012;40(2):436-445.

40. Yekrang Sis H, Rashedi J, Azabdaftari F, et al. An innovative method to enhance the modified DOTS for TB patients. Tanaffos. 2015;14(3):177.

41. Zhang H, Ehiri J, Yang H, Tang S, Li Y. Impact of community-based DOT on tuberculosis treatment outcomes: a systematic review and meta-analysis. PLoS One. 2016;11(2):e0147744.

42. Kibret KT, Moges Y, Memiah P, Biadgilign S. Treatment outcomes for multidrug-resistant tuberculosis under DOTS-Plus: a systematic review and meta-analysis of published studies. Infect Dis Poverty. 2017;6(1):7.

43. Bock NN, Jensen PA, Miller B, Nardell E. Tuberculosis infection control in resource-limited settings in the era of expanding HIV care and treatment. J Infect Dis. 2007;196(Suppl 1):S108-S113.

44. Chaisson RE, Churchyard GJ. Recurrent Tuberculosis: Relapse, Reinfection, and HIV. Chicago: The University of Chicago Press; 2010. 


\section{Supplementary materials}

Chest radiographs for Patients 1-4 (no images available for Patient 5).

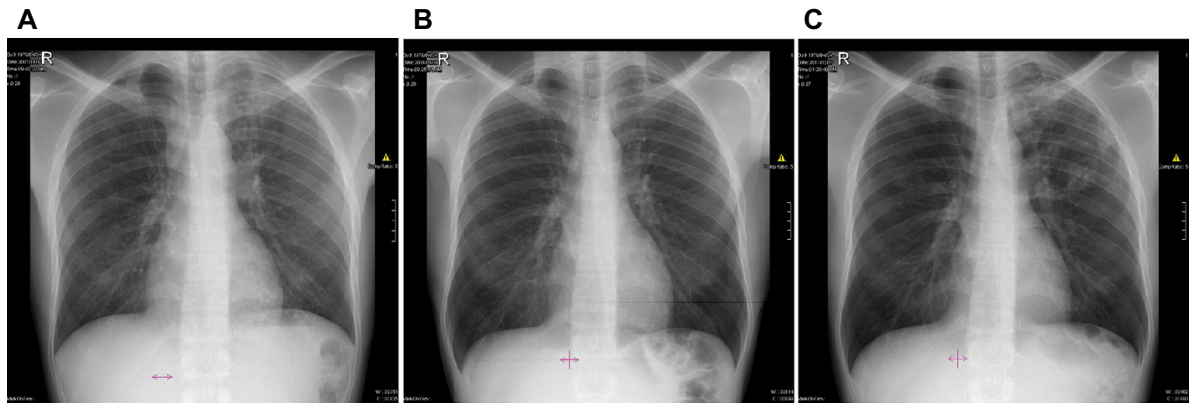

Figure SI Chest X-rays of Patient I depicting (A) infiltrates on both lungs; (B) persistent fibrosis in the left lung; and (C) cavities in the left lung.

A

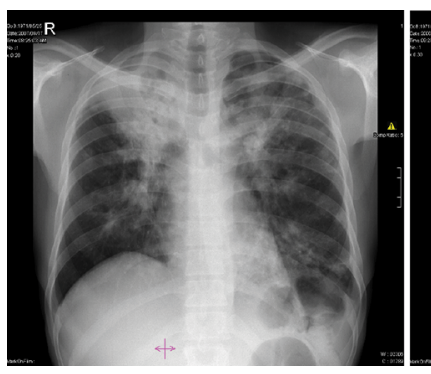

B

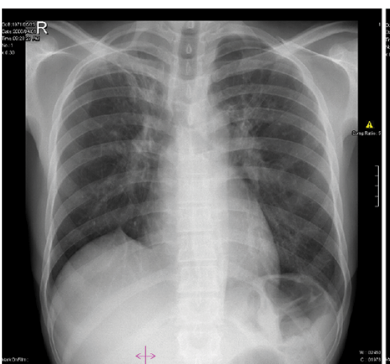

C

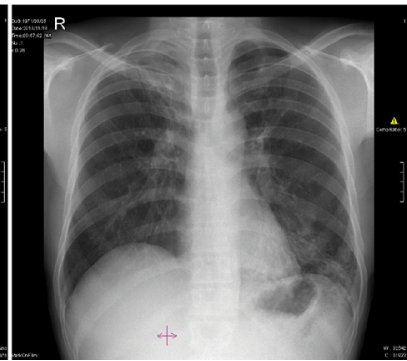

Figure S2 Chest X-rays of Patient 2 depicting $(\mathbf{A})$ infiltrates in both lungs and cavities in the left lung; (B) right upper lobe fibrosis; and (C) infiltrates in the right lung and infiltrates and new lesions in the left lung.

\section{A}

B

C
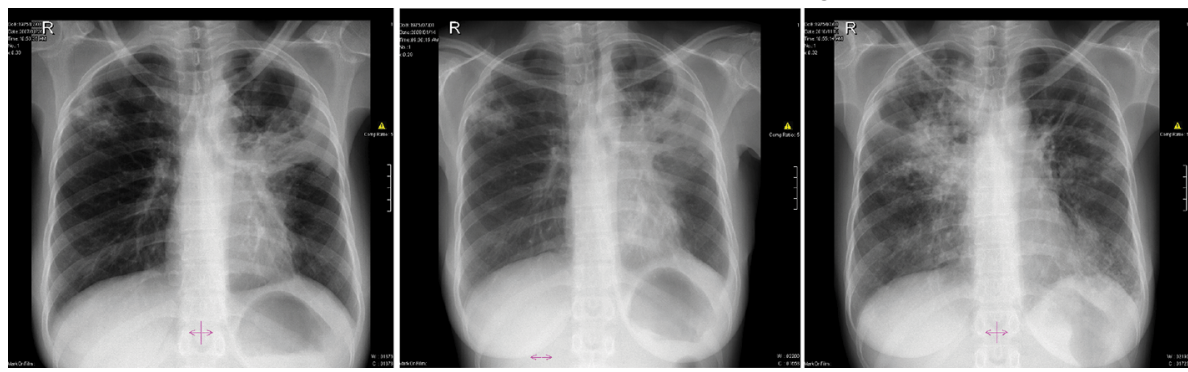

Figure S3 Chest X-rays of Patient 3 depicting (A) cavities and infiltrates in both lungs; (B) cavities and infiltrates on the right lung and fibrosis in the left lung; and (C) cavities, infiltrates, and patchy consolidation in the right lung and consolidation in mid and lower zones of the left lung.

A

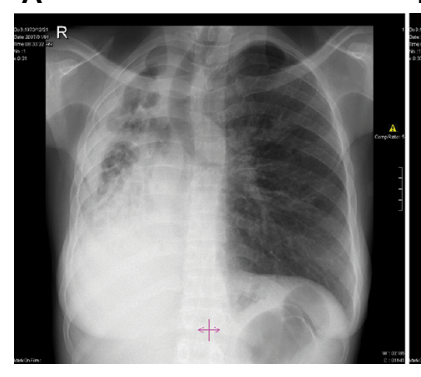

B

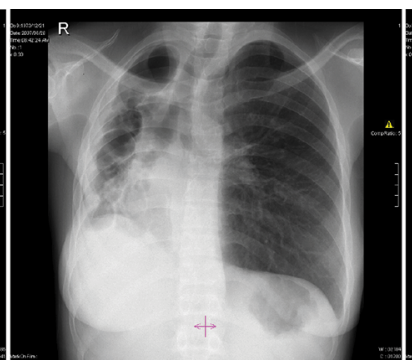

C

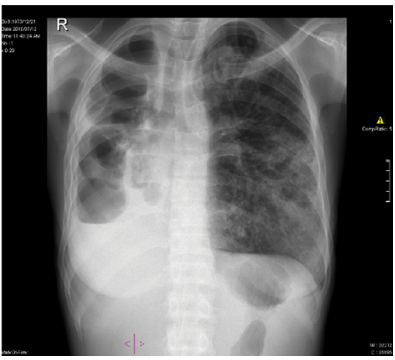

Figure S4 Chest X-rays of Patient 4 depicting (A) vast damage to the right lung with cavities, infiltrates, pleural disease, shrinkage, and destruction. Minimal damage to the left lung; (B) residual widespread damage to the right lung; and (C) right lung bullae and new pleural effusion. New infiltrates in left lung. 
Infection and Drug Resistance is an international, peer-reviewed openaccess journal that focuses on the optimal treatment of infection (bacterial, fungal and viral) and the development and institution of preventive strategies to minimize the development and spread of resistance. The journal is specifically concerned with the epidemiology of antibiotic resistance and the mechanisms of resistance development and diffusion in both hospitals and the community. The manuscript management system is completely online and includes a very quick and fair peerreview system, which is all easy to use. Visit http://www.dovepress.com/ testimonials.php to read real quotes from published authors.

Submit your manuscript here: https://www.dovepress.com/infection-and-drug-resistance-journal 